\title{
SURVIVAL RATE AND GROWTH OF JUVENILE SANDFISH (Holothuria scabra) IN VARIOUS REARING CONDITIONS
}

\author{
Lisa Fajar Indriana ${ }^{1}$, Muhammad Firdaus ${ }^{1}$, Supono $^{2}$ and Hendra Munandar ${ }^{1}$ \\ ${ }^{1}$ Research and Development Division for Marine Bio Industry. Research Center for Oceanography - \\ Indonesian Institute of Science (LIPI). \\ ${ }^{2}$ Bitung Technical Implementation Unit for Marine Life Conservation. Research Center for Oceanography - \\ Indonesian Institute of Science (LIPI). \\ *Correspondence author: lisaindriana23@gmail.com
}

Received: December 2016 Accepted: January 2017

\begin{abstract}
Techniques for producing Holothuria scabra or sandfish sea cucumbers from aquaculture have been developed rapidly in the recent years to address the issues of decreasing sandfish population and increasing market demand. During the process of culturing $H$. scabra, the early stages of sandfish (i.e. larvae and juvenile) are the most critical of the development. Therefore, the Research and Development Division of the Marine Bio Industry LIPI conducted a study to assess the growth performance of juvenile $H$. scabra cultured in four different rearing conditions: (i) indoor concrete tank, (ii) indoor fiberglass tank, (iii) outdoor concrete tank with $1 \mathrm{~mm}$ hapa mesh, and (iv) outdoor concrete tank with $3 \mathrm{~mm}$ hapa mesh. Each of the rearing condition was set with an initial juvenile density of 15 juveniles per tank with a mean initial weight of $14 \mathrm{~g}$, and fed ad libitum with a mixed feed consisting of Enhalus acoroides sea grass, Pennisetum purpureum napier and cow manure. The experiments were conducted for 20 weeks between April 26 - September 23, 2013. After the experimental period, juveniles reared in the outdoor concrete tank with $1 \mathrm{~mm}$ mesh show the best performance with respect to their survival rate (48.89 $\pm 3.85 \%)$, mean final weight $(22.07 \pm 1.01 \mathrm{~g})$, final biomass $(162.05 \pm 18.17 \mathrm{~g})$ and specific growth rate $(0.15 \pm 0.03 \%$ per day $)$. Further studies that combine rearing conditions with different bottom substrates as well as investigating the effect of light are needed to optimize the production of $H$. scabra from aquaculture.
\end{abstract}

Keywords: Holothuria scabra, growth, aquaculture, juvenile, tank

\section{INTRODUCTION}

Indonesia is currently increasing its sea cucumbers production, therefore several national strategic steps have been put forward including aquaculture that could supplement wild capture production. Over-exploitation has been threatening the sustainability of sea cucumbers production, more so in the face of a growing market demand. Between 2005-2014, capture-based sea cucumbers production in Indonesia reached an average increase of $0.81 \%$, or equivalent to 5,428 tons in 2014 (DGCF, 2015). To further increase its production of sea cucumbers over the period
2015 - 2019, Indonesia has designed a 174,600 ha area for aquaculture development (DGA, 2015).

Although several techniques for increasing sea cucumbers production in hatcheries or aquaculture have been established (e.g. Battaglene, 1999; Pitt, 2001; Agudo, 2006), the mass production of sea cucumbers still faces issues with respect to production cost, nursery technology and survival rate of cultured juveniles. For example, the rearing of juvenile $H$. scabra in earthen seawater ponds, sea pens and sea cages takes at least two years to reach the commercial sizes of 0.7 - 1 kg (Purcell, 2004; Bell et al., 2007; Purcell and Simutoga, 2008). 
Moreover, the survival rate and growth performance of juvenile $H$. scabra during their early stages are relatively low. Technologies for culturing the early stages of sandfish are available, particularly rearing methods for newly settled juveniles using staked plates and sand in rearing tanks (Battaglene, 1999; Pitt, 2001). However, optimizing the growth performance of juvenile sandfishes during their grow-out stage is still a challenge. For instance, Purcell (2004) reported that the survival rates of juvenile $H$. scabra (3 $15 \mathrm{~g}$ ) released in sea pens or sea ranch only range between $10-30 \%$.

The use of artificial feed to increase the growth of juveniles has been explored, yet at the cost of more expensive ingredients. Seaweed (Sargassum sp.) has been suggested as the best ingredient for formulated powder feed (Wu et al., 2015). However, the exploitation of seaweed as a source of artificial feed raises a sustainability concern for aquaculture development. Therefore, substituting seaweed with highly available terrestrial plants has also been developed for feeding sandfishes to lower the production cost (Xia et. al., 2012; Wu et al., 2015).

Besides nutrients from formulated feed, the surface area of nursery tank where juvenile sandfishes live in is also a major factor for their grow-out stage. $H$. scabra sandfishes are deposit feeders and require a large surface area for foraging (Bell et al., 2007). Competition for space impedes the growth of holothurian juveniles, where overcrowding reduces their growth rates due to the lack of food or malnutrition, while increasing size variability (Liu et al., 2004). The growth of juvenile sandfishes significantly decreases when reaching a biomass of $225 \mathrm{~g} / \mathrm{m}^{2}$ of tank floor space (Battaglene et al., 1999).

Physical aspects of rearing tanks may play an important role in producing natural food sources as diatom film and bacteria (biofilm) can attach to the tank wall (e.g. Battaglene, 1999). Rearing tanks for juvenile sandfishes conventionally use rectangular concrete tanks, but recently fiberglass tanks have been used as well. While the use of various rearing tanks has been massively applied, it is not well understood whether there is any difference between the growth performances of juvenile $H$. scabra reared in different types of tank.

Therefore this study aims to investigate the survival rate and growth of juvenile Holothuria scabra reared in various rearing conditions. In line with the effort to optimize sea cucumbers production from aquaculture, the Research and Development Division of the Marine Bio Industry - LIPI located in West Nusa Tenggara has been conducting research on the aquaculture of $H$. scabra. In 2011, the Research and Development Division has developed artificial feeds sourced from various terrestrial plants including napier grass (Pennisetum purpureum). The mixed of napier grass with sea grass (Enhalus acoroides) and cow manure can be used as a substitute feed for juvenile H. scabra (Dwiono, pers. comm). Moreover, the research unit is located within the Fisheries Management Area (FMA) 713 covering the Makassar Strait, Bone Bay, Flores and Bali Sea, which supports the highest percentage (41\%) of wild captured sea cucumbers production in Indonesia in 2014 (DGCF, 2015).

\section{MATERIALS AND METHODS}

The juveniles of H. scabra used in the experiments were from the hatchery of the Research and Development Division of the Marine Bio Industry - LIPI. A total of 180 juveniles with an initial mean weight of $14 \mathrm{~g}$ was used. The juveniles were reared for 20 weeks (April 26 - September 23, 2013) under four different rearing conditions, which are: (i) indoor concrete tanks with $1 \mathrm{~mm}$ hapa mesh (ICT $1 \mathrm{~mm}$ ), (ii) indoor fiberglass tanks with $1 \mathrm{~mm}$ hapa mesh (IFT $1 \mathrm{~mm}$ ), (iii) outdoor concrete tanks with 1 $\mathrm{mm}$ hapa mesh (OCT $1 \mathrm{~mm}$ ), and (iv) outdoor concrete tanks with $3 \mathrm{~mm}$ hapa mesh (OCT 3 $\mathrm{mm})$. See Table 1 for details. Each treatment was conducted in triplicates and stocked with 15 
juveniles.

Table 1. Set up of the four rearing conditions.

\begin{tabular}{ll}
\hline Treatment & Description \\
\hline & Indoor Concrete Tank \\
& Tank dimension: $400(\mathrm{~L}) \times 50(\mathrm{~W}) \times$ \\
ICT-1 mm & $50(\mathrm{H}) \mathrm{cm}$. Floating hapa frame: $100 \times$ \\
& $20 \times 20 \mathrm{~cm} .1 \mathrm{~mm}$ mesh size. \\
& Indoor Fiberglass Tank \\
& Tank dimension: $400 \times 80 \times 75 \mathrm{~cm}$. \\
& Floating hapa frame: $100 \times 20 \times 20 \mathrm{~cm}$. \\
& 1 mm mesh size. \\
& Outdoor Concrete Tank \\
& Tank dimension: $500 \times 200 \times 100 \mathrm{~cm}$. \\
& Floating hapa frame: $100 \times 20 \times 20 \mathrm{~cm}$. \\
& 1 mm mesh size. \\
& Outdoor Concrete Tank \\
& Tank dimension: $500 \times 200 \times 100 \mathrm{~cm}$. \\
& Floating hapa frame: $100 \times 20 \times 20 \mathrm{~cm}$. \\
& 3 mm mesh size. \\
\hline
\end{tabular}

A formulated feed consisted of Enhalus acoroides sea grass (40\%), Pennisetum purpureum napier grass (30\%) and cow manure (30\%) was given ad libitum during the rearing period. The tanks were ccontinuously aerated and $75 \%$ of the water was changed every 3 days. Weekly water quality was conducted on the tanks. Juveniles from each treatment were assessed for their survival rate and individual weight every 2 weeks.

At the end of the experiment, the survival rate (SR), the specific growth rate (SGR) and the final biomass (FB) of juveniles were estimated following Zhou et al., (2006) and Ju et al., (2015):

$$
\mathrm{SR}=(\mathrm{Nt} / \mathrm{No}) \times 100 \%
$$

where SR is the survival rate (\%), $\mathrm{N}_{\mathrm{t}}$ and $\mathrm{N}_{0}$ are the final and initial numbers of biota, respectively.

$$
\mathrm{SGR}=100\left(\ln \mathrm{W}_{\mathrm{t}}-\ln \mathrm{W}_{0}\right) / \mathrm{t}
$$

where SGR is the specific growth rate (\% per day), $\mathrm{W}_{0}$ is the initial wet weight $(\mathrm{g}), \mathrm{W}_{\mathrm{t}}$ is the final wet weight $(\mathrm{g})$, and $\mathrm{t}$ is the length of culturing period (days).

$$
\mathrm{FB}=\mathrm{W}_{\mathrm{t}} \times \mathrm{N}_{\mathrm{t}}
$$

where FB is the final biomass $(\mathrm{g})$. $\mathrm{W}_{\mathrm{t}}$ is the final wet weight $(\mathrm{g})$ and $\mathrm{N}_{\mathrm{t}}$ is the final number of biota.

\section{Statistical Analysis}

Data on the effect of various rearing conditions on the growth performance of juvenile $H$. scabra are analyzed with the one-way analysis of variance (ANOVA) at a significance level of 0.05 using the SPSS software (version 22). The Tukey post-hoc test is applied to investigate any significant difference between treatments.

\section{RESULTS}

\section{Survival Rate}

The survival rates of juvenile $H$. scabra in all types of tank decrease during the rearing period with less than $50 \%$ at the end of the experiments (Figure 1). It appears that the week 10 is a critical period when juveniles started to die with steady mortality rates afterwards. Juveniles reared in the OCT $1 \mathrm{~mm}$ experiment show the highest

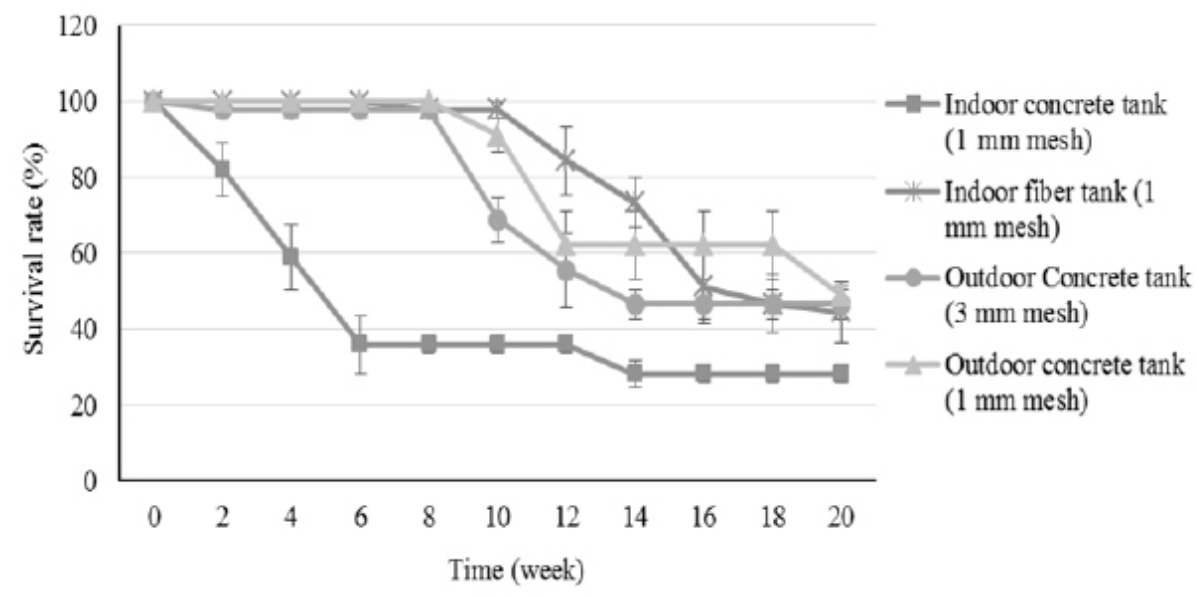

Figure 1. Survival rates (mean $\pm \mathrm{se}$, in\%) of juvenile H. scabra under the four rearing conditions. 
survival rate $(48.89 \pm 2.22 \%)$, while those in the ICT $1 \mathrm{~mm}$ experiment demonstrate the lowest survival rate $(28.21 \pm 2.29 \%)$. However, our data analysis shows no statistically significant difference between final survival rates under the four different rearing conditions $(p>0.05)$.

\section{Growth}

Juveniles reared in the four types of tank show a general increase in growth, except for those in the IFT $1 \mathrm{~mm}$ experiment that show more stable weights during the rearing period (Figure 2). The weights of juvenile $H$. scabra fluctuated at the beginning of the rearing period before eventually increased starting the week 12. Meanwhile, juveniles reared in the IFT $1 \mathrm{~mm}$ experiment show a slightly decreased mean weight during the rearing period from $13.76 \pm 0.52 \mathrm{~g}$ to $11.81 \pm$

\section{$2.75 \mathrm{~g}$.}

Most final weights of juvenile $H$. scabra from different rearing conditions are significantly different $(\mathrm{p}<0.05)$. The final weights of juveniles reared in the IFT $1 \mathrm{~mm}(11.81 \pm 4.76 \mathrm{~g})$ and OCT $3 \mathrm{~mm}(18.60 \pm 3.48 \mathrm{~g})$ tanks are significantly different from the rest. Whereas the ICT $1 \mathrm{~mm}$ $(27.41 \pm 3.98 \mathrm{~g})$ and the OCT $1 \mathrm{~mm}(22.07 \pm 1.01$ g) tanks are not significantly different from each other.

The specific growth rate (SGR) of juveniles reared in the IFT $1 \mathrm{~mm}$ experiment shows a significantly $(p<0.05)$ lower value $(-0.07 \pm 0.09$ $\mathrm{g}$ per day) than the rest (Figure 3). Whereas the SGRs for the ICT $1 \mathrm{~mm}(0.22 \pm 0.05 \mathrm{~g}$ per day), the OCT $1 \mathrm{~mm}(0.15+0.03 \mathrm{~g}$ per day $)$ and the OCT $3 \mathrm{~mm}(0.11+0.14 \mathrm{~g}$ per day $)$ experiments are not statistically different from each other.

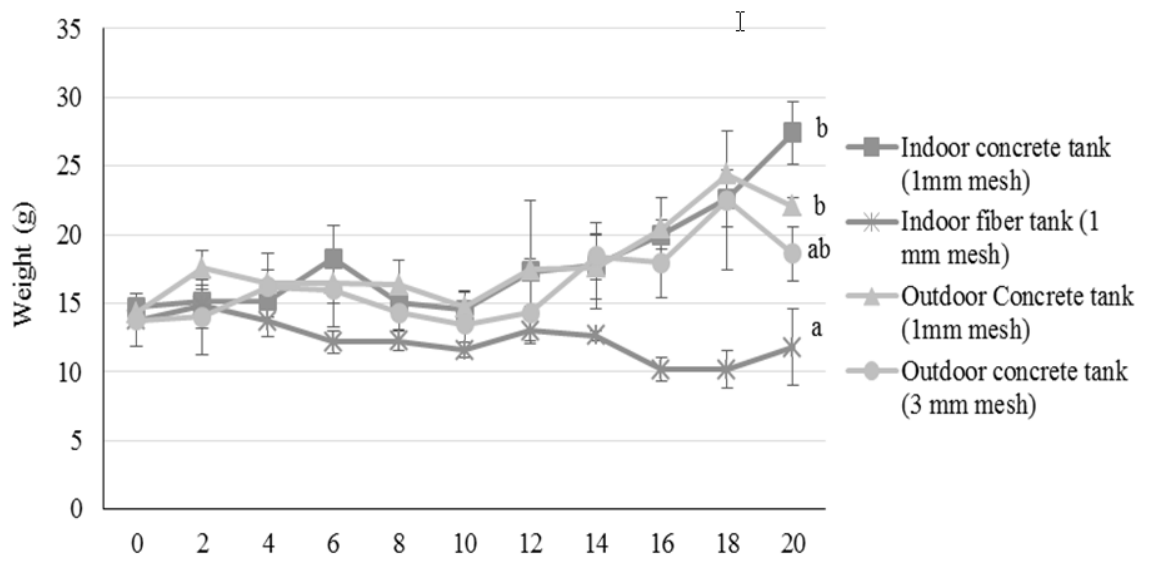

Figure 2. Weights (mean $\pm \mathrm{SE}$, in gram) of juvenile $H$. scabra under the four rearing conditions. Mean values noted by different letters are significantly different from one another.

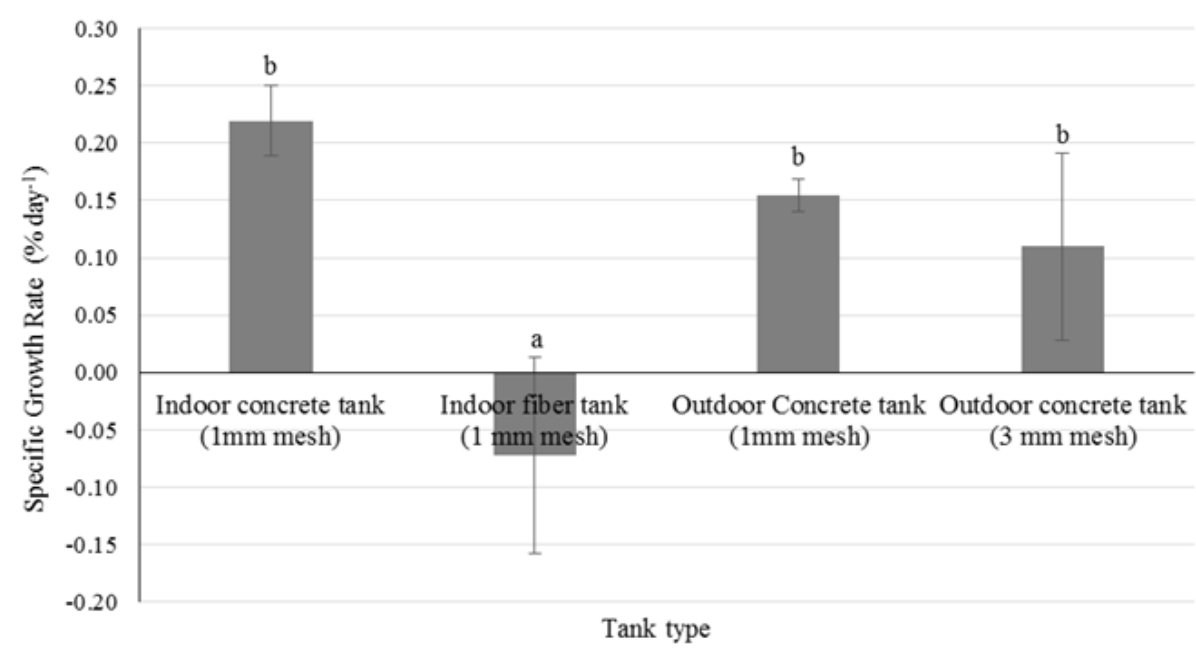

Figure 3. Specific growth rates (mean $\pm \mathrm{SE}$ in \% per day) of juvenile $H$. scabra under the four rearing conditions. Mean values noted by different letters are significantly different from one another. 


\section{Final Biomass}

Data on the final biomass (FB) of juveniles reared in the four types of tank (Figure 4) reveal that the OCT $1 \mathrm{~mm}$ experiment yields the highest FB $(162.05 \pm 10.49 \mathrm{~g})$ compared to the ICT $1 \mathrm{~mm}$ (101.84 $\pm 16.44 \mathrm{~g})$, OCT $3 \mathrm{~mm}(112.37 \pm 17.58$ $\mathrm{g})$ and IFT $1 \mathrm{~mm}(61.84 \pm 6.40 \mathrm{~g})$ tanks. And, the estimated FBs of the ICT $1 \mathrm{~mm}$ and OCT $3 \mathrm{~mm}$ experiments are not significantly different.

\section{DISCUSSION}

Cost-effective methods for mass rearing of juvenile sea cucumbers have been recently developed. These include applying co-culture with other species such as tilapia (Sithisak et al., 2013), Kappaphycus striatum red seaweed (Beltran-Gutierrez et al., 2014), Litopenaeus stylirostris shrimp (Bell et al., 2007) and Penaeus monodon black tiger shrimp (Lebata-Ramos et al., 2012), as well as substituting natural feeds with terrestrial plants ( $\mathrm{Wu}$ et al., 2015) and applying different grow-out rearing techniques (Purcell, 2004; Lavitra et al., 2010; Purcell and Agudo, 2013). Currently, there are two reported common methods for commercial mass-rearing of juvenile holothurians, which are plate-culture (for the early larval stage, up to $13 \mathrm{~mm}$ juveniles) and bottom-culture (for $>20 \mathrm{~mm}$ juveniles (Battaglene, 1999).

In general, the survival rates of juvenile $H$. scabra in this study are relatively high compared to previous works. Battaglene et al. (1999) reported that the survival rate of juvenile $H$. scabra reared in concrete square tank with different types of substrate range between $4.5-34.0 \%$. Meanwhile, juvenile $H$. scabra reared in fiber tank and fed with Algamac demonstrate a $34 \%$ of survival rate (Pitt, 2001). In all, previous works showed that variation in the survivorship and growth rate of sea cucumbers are associated not only with rearing techniques, but also the initial stocking density, bottom substrates, commercial feed and environmental conditions during rearing period (Qiu et al., 2014; Tolon et al., 2015; Giraspy and Ivy, 2008; Lavitra, 2010).

In this study, water quality during the rearing period was maintained at the optimum level for the growth of juvenile $H$. scabra $(25.35 \pm$ 0.01 to $29.35 \pm 1.11^{\circ} \mathrm{C}$ for temperature, 28.50 \pm 0.78 to $34.81 \pm 0.51 \mathrm{ppt}$ for salinity, $7 \pm 0.16$ to $8.15 \pm 0.28$ for $\mathrm{pH}$ ). These ranges of water quality parameters are similar to the optimum environmental conditions reported in existing studies (Battaglene et al., 1999; Mercier et al., 1999; Utchike, 2001; Pitt and Duy, 2004).

In this study, the use of different mesh sizes in the outdoor concrete tanks demonstrates no significant effect on the growth performance of juvenile $H$. scabra, while the different tank types (fiber glass versus concrete) show significant differences in the SGR and growth of juvenile $H$. scabra. The SGR and growth of juveniles reared in the concrete tanks (both indoor and outdoor ones) are higher than of those reared in the fiberglass tanks. Limited information is available for studies that compare the effect of different tanks (fiberglass and concrete) on the SGR and growth of juvenile $H$. scabra as most of previous studies focused on the application of different techniques (i.e. pond system, plastic tank) and/ or using different feed formulas. For instance, Sithisak et al. (2013) showed higher SGR for juvenile $H$. scabra reared in round plastic ponds and fed by shrimp feed $(0.27 \pm 0.28 \mathrm{~g})$.

Looking at the effects of indoor versus outdoor rearing tanks, there are noticeable differences in the SGRs and growths under these different set-ups. The lowest growth performance (weekly weight gain, SGR and final biomass) is demonstrated by juveniles reared in the fiberglass tank placed indoor. As the indoor tank was not equipped with a light source, the indoor tanks likely had lower light intensity (data on light intensity was not recorded). Dong et al. (2011) reported the effects of photoperiod on holothurians of other species (Apostichopus japonicus). Low light availability during rearing period significantly affected the movement and reduced feeding time of this sea cucumber compared to those reared under natural light cycle. In our study, juvenile $H$. scabra were exposed to continuous low light intensity. Thus, we speculate that the low survival rate and growth of juvenile $H$. scabra reared in the indoor fiber experiment is also possibly due to low feeding rate.

We observe a positive relationship between light availability and the growth performance of juvenile $H$. scabra that may be associated with their juvenile density and total biomass. Low density and biomass minimize competition for 


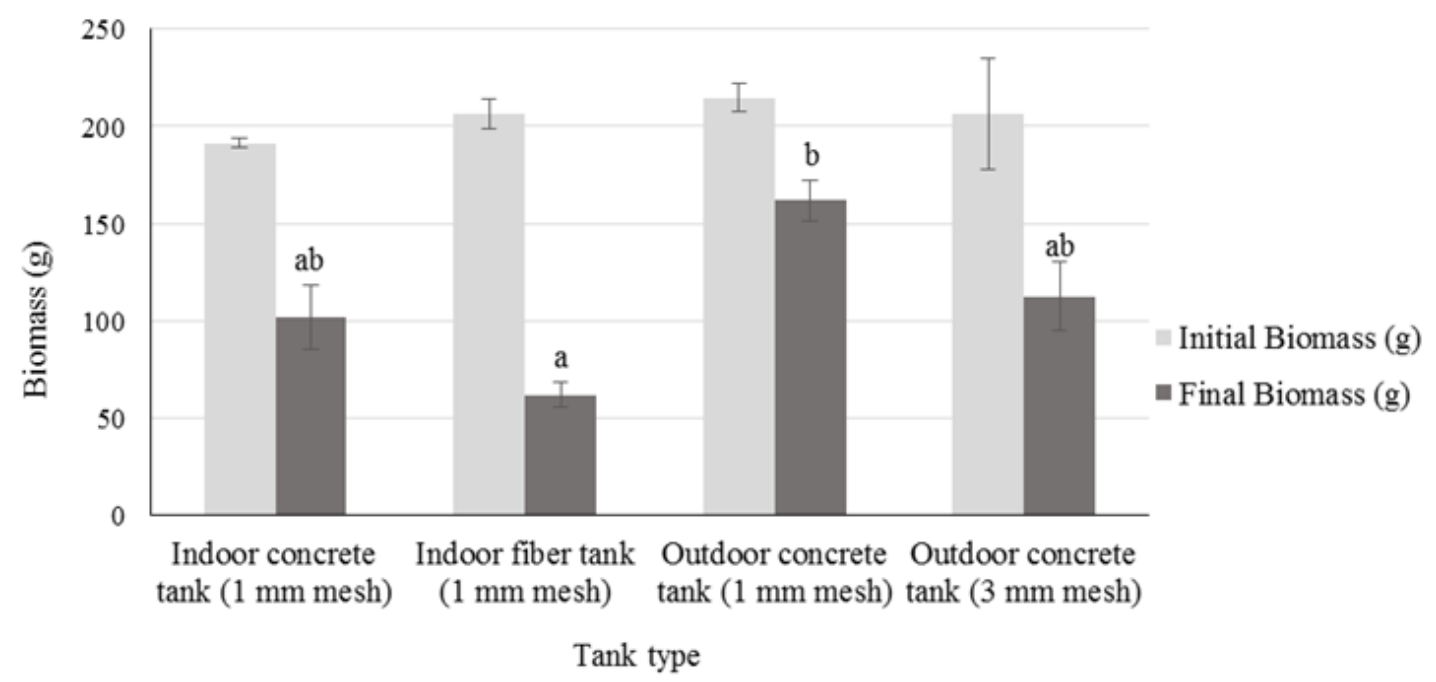

Figure 4. Mean \pm SE biomass of juveniles $H$. scabra reared in various types of tanks. Means with different letters are significantly different from one another.

space and food between biota. The adverse effects of density have been widely documented during the grow-out of juvenile holothurians (Battaglene and Bell, 1999; Liu et al., 2004; Lavitra, 2010; Ramofafia et al., 1997). The study of Asha and Diwakar (2013) showed that the growth rate of juveniles $H$. scabra decreased gradually with increasing stocking density. The recommended stocking density to achieve maximum growth rates varies depending on the size of juveniles, habitat condition, natural food availability and water changes. A range of 2 to 20 juveniles per $\mathrm{m}^{2}$ is recommended, with 10 juveniles per $\mathrm{m}^{2}$ being a commonly used density (Asha and Diwakar, 2013).

Light intensity also has been associated with the growth of diatom or epiphytic microalgae as natural food sources for juvenile H. scabra in aqualculture. Reduced light intensity have been shown to lower the growth of diatoms and microalgae (Battaglene, 1999; Lopes et al., 2009). In our study, the biomass of diatom or epiphytic microalgae between indoor and outdoor tank was not recorded during the experiments.

\section{CONCLUSION}

Our findings suggest that concrete tank and outdoor rearing condition provide higher growth performance of juvenile $H$. scabra for aquaculture as assessed from their higher survival and specific growth rate, average final body weight and final biomass. Whereas the use of different sizes of hapa mesh does not any significant effect the growth of juveniles.

Further studies are needed to validate the growth performance of juvenile $H$. scabra reared in different tank types and conditions to understand their optimum growth rate. Future works could include investigating the effect of different photoperiod cycles, tank material that may stimulate the growth of microalga as natural food sources for the juveniles, as well as the effect of tank colors in relation to the feeding behavior of juveniles.

\section{ACKNOWLEDGEMENT}

This study would not be possible without funding support from the Research and Development Divison for Marine Bio Industry LIPI, Mataram. We also would like to thank Dr. Sigit A.P. Dwiono, Nurhalis Tarmin and Abdul Wahab for providing H. scabra juveniles. Finally, we thank anonymous reviewers for comments that improved the quality of our manuscript.

\section{REFERENCES}

Agudo, N.S.(2006). Sandfish hatcherytechniques. Australian Centre for International Agricultural Research, the Secretariat of 
the Pacific Community, and the World Fish Centre. Australia, $44 \mathrm{pp}$.

Asha, P. S. and Diwakar, K. (2013). Effect of stocking density on the hatching rate, larval and early juvenile rearing of edible sea cucumber Holothuria scabra (Jaeger, 1883). Indian J. Geo-Mar. Spec., 42 (2): 191-195.

Battaglene, S. C. (1999). Culture of topical sea cucumbers for stock restoration and enhancement. Naga-The ICLARM Quarterly, 22: 4-11.

Battaglene, S. C., Seymour, J. E. and Ramofafia, C. (1999). Survival and growth of cultured juvenile sea cucumbers, Holothuria scabra. Aquac., 178: 293-322.

Battaglene, S. C. and Bell, J. D. (1999). Potential of the tropical Indo-Pacific sea cucumber, Holothuria scabra for stock enhancement. In: Howell, B. R., Moksness, E. and Swasan, T. (Eds) Proceedings of the first international symposium on stock enhancement and sea ranching. 478-490.

Bell, J, Agudo, N., Purcell, S., Blazer, P. and Simutoga, M. (2007). Grow-out of sandfish Holothuria scabra in ponds shows that coculture with shrimp Litopenaeus stylirostris is not viable. Aquac., 273: 509-519.

Beltran-Guiterrez, M., Ferse, S. C. A., Kunzmann, A. and Slater, M. J. (2014). Co-culture of sea cucumber Holothuria scabra and red seaweed Kappaphycus striatum. Aquac. Res., 47 (5): 1-11.

DGA (Directorate General of Aquaculture), (2015). Strategic plan of Directorate General of Aquaculture, Indonesia 20152019.Directorate General of Aquaculture. 38 pp.

DGCF (Directorate General of Capture Fisheries), (2015). Statistics of marine capture fisheries by fisheries management area (FMA), 2005-2014. Directorate General of Capture Fisheries, Indonesia. 486 pp.

Dong, G., Dong, S. Tian, $\mathrm{X}$ and Wang, F. (2011). Effects of photoperiod on daily activity rhythm of juvenile sea cucumber, Apostichopus japonicas (Selenka). Chinese J. Oceanol. Limnol., 29 (5): 1015-1022.
Giraspy, D. A. B. and Ivy, G. (2008). The influence of commercial diets on growth and survival in the commercially important sea cucumber Holothuria scabra var. versicolor (Conand, 1986) (Echinodermata: Holothuroidea). SPC Beche-de-mer Inf. Bul., 28: 46-52.

Ju, B., Chen, L., Xing, R. and Jiang, A. (2015). A new integrated multitrophic aquaculture system consisting of Styela clava, microalga and Sticophus japonicus. Aquac. Int., 23 (2): 471-497.

Lavitra, T., Rasolofonirina, R., Grosjean, P., Jangoux, M. and Eeckhaut, I. (2009). The effect of food quality and rearing density on the growth and survival of epibenthic juveniles of the sea cucumber Holothuria scabra. Western Indian Ocean J. Mar. Sci., 8(1): 87-95.

Lavitra, T., Fohy, N., Gestin, P. G., Rasolofanirina, R. and Eeckhaut, I. (2010). Effect of water temperature on the survival and growth of endobenthic Holothuria scabra (Echinodermata: Holothruoidea) juveniles reared in outdoor ponds.SPC Beche-de-mer Inf. Bul., 30:25-30.

Lavitra, T., Rasolofonirina, R. and Eeckhaut, I. (2010). The effect of sediment quality and stocking density on survival and growth of the sea cucumber Holothuria scabra reared in nursery ponds and sea pens. Western Indian Ocean J. Mar. Sci., 9 (2): 153-164.

Lebata-Ramos, M. J. H., Solis, E. F. D., Sibonga, R. C. and Satoshi, W. (2012). Co-culture trials of sandfish Holothuria scabra and black tiger shrimp Penaeus monodon in mangrove. In Tanaka, K., Morioka, S. and Watanabe, S. (Eds) Sustainable stock management and development of aquaculture technology suitable for Southeast Asia (JIRCAS working report No. 75); 87-95.

Liu, X., Zhu, G., Zhao, Q., Wang, L. and Gu, B. (2004). Studies on hatchery techniques of the sea cucumber, Apostichopus japonicus, In: Lovatelli, A., Purchell, C., Uthcike, S., Hamel, J. F. and Mercier, A. (eds). Advances in sea cucumber aquaculture and management. FAO fisheries technical paper 463:287-295. 
Lopes, E. J., Scoparo, C. H. G, Lacerda, L. M. C. F. and Franco, T. T. (2009). Effects of light cycles (night/day) on $\mathrm{CO}_{2}$ fixation and biomass production by microalgae in photobioreactors. Chem. Eng. Process. Process Intensif., 48 (1): 306-309.

Mercier A., Battaglene S. C. and Hamel, J. F. (1999). Daily burrowing cycle and feeding activity of juvenile sea cucumbers Holothuria scabra in response to environmental factors. J. Exp. Mar. Bio. Ecol., 239 (1):125-156.

Pitt, R. and Duy, N. D. Q. (2004). Breeding and rearing of the sea cucumber Holothuria scabra in Vietnam. p. 333-346. In: Lovatelli A., Conand C., Purcell S., Uthicke S., Hamel, J. F. and Mercier A. (eds). Advances in sea cucumber aquaculture and management. Fisheries Technical Paper No. 463. FAO, Rome.

Pitt, R. (2001). Review of sandfish breeding and rearing methods. SPC Beche-de-mer Inf. Bull., 14: 14-21.

Purcell, S. W. and Agudo, N. S. (2013). Optimisation of mesh enclosures for nursery rearing of juvenile sea cucumbers. PLOS one, 8 (5): 1-10.

Purchell, S.W., Hair, C. and Mills, D. (2012). Sea cucumber culture, farming and ranching in the tropics: progress, problems and opportunities. Aquac., 368: 219-224.

Purcell, S.W. and Simutoga, M. (2008). Spatiotemporal and size-dependent variation in the success of releasing cultured sea cucumbers in the wild. Rev. Fish Sci., 16: 204-214.

Purcell, S.W. (2004). Rapid growth and bioturbation activity of the sea cucumber Holothuria scabra in earthen ponds. Proc. Australasian Aquac., 2004: 244.

Qiu, T., Zhang, L., Zhang, T. and Yang, H. (2014). Effects of mud substrate and water current on the behavioral characteristics and growth of the sea cucumber Apostichopus japonicas in the Yuehu lagoon of northern China. Aquac. Int., 22 (2): 423-433.

Ramofafia, C., Foyle, T. P. and Bell, J. D. (1997). Growth of juvenile Actinopyga mauritiana (Holothuroidea) in captivity. Aquac., 152: 119-128.

Sithisak, P., Pongtippatee, P. and Withyachumnarnkul, B. (2013). Improving inland culture performance of sea cucumbers, Holothuria scabra, by co-culture with red tilapia. Songklanakarin J. Sci. Tech., 35 (5): 501-505.

Tolon, T., Emiroglu, D., Gunay, D. and Saygi, H. (2015). Effect of sediment grain size on growth performance of juvenile sea cucumber Holothuria tubulosa. Turkish J. Fish.Aquat. Sci., 15: 555-559.

Uthicke, S. (2001). Interactions between sediment feeders and microalgae on coral reefs: grazing losses versus production enhancement. Mar. Ecol. Prog. S., 210:125-138.

Xia, S., Hongsheng, Y. and Yong, L. (2012). Effects of different seaweed diets on growth, immunity and water quality of the sea cucumber Apostichopus japonicus (Selenka). Aquac. Nutr., 19: 382-389.

Wu, B., Xia, S., Rahman, M. M., Rajkumar, M., Fu, Z., Tan, J. and Yang, A. (2015). Substituting seaweed with corn leaf in diet of sea cucumber (Apostichopus japonicus): effects on growth, feed conversion ratio and feed digestibility. Aquac., 444: 88-92.

Zhou, Y., Yang, H., Liu, S., Yuan, X., Mao, Y., Liu, Y., Xu, X and Zhang, F. (2006). Feeding and growth on bivalve biodeposits by the deposit feeder Stichopus japonicus Selenka (Echinodermata: Holothuroidea) co-cultured in lantern nets. Aquac., 256: 510-520. 